\title{
FAKTOR - FAKTOR YANG BERHUBUNGAN DENGAN KEPUASAN PASIEN RAWAT INAP TERHADAP PELAKSANAAN KONSELING GIZI DI RUMAH SAKIT HOLISTIC PURWAKARTA
}

\author{
Ipah Sri Astuti ${ }^{1}$, Ahmad Yani $^{2}$, Naintina Lisnawati ${ }^{3}$ \\ ${ }^{1,2,3}$ Sekolah Tinggi Ilmu Kesehatan Holistik, Purwakarta
}

\begin{abstract}
ABSTRAK
Latar Belakang: Selama ini pelayanan gizi di Rumah Sakit Holistic Purwakarta belum pernah melakukan evaluasi tentang layanan konseling gizi dilihat dari segi kepuasan pasien. Proses evaluasi ini sangat penting dilakukan karena berkaitan dengan aspek-aspek yang menjadi prioritas utama dalam pelayanan konseling gizi yaitu mencakup sikap konselor, materi, media, metode, lama, dan tempat konseling.

Tujuan: Mengetahui faktor-faktor yang berhubungan dengan kepuasan pasien rawat inap terhadap pelaksanaan konseling gizi di Rumah Sakit Holistic Purwakarta..

Metode: Jenis penelitian observasional dengan pendekatan cross sectional. Jumlah sampel penelitian 32 pasien di Rumah Sakit Holistic Purwakarta.Faktor faktor yang diteliti sikap konselor, materi, media, metode, waktu, dan tempat konseling.Data diperoleh menggunakan angket.Analisis data menggunakan UjiFisher Exact Test.

Hasil: Penilaian responden terhadap sikap konselor 68,8\% puas, materi konseling $87,5 \%$ puas, media $50 \%$ puas, metode konseling $46,9 \%$ puas, lama konseling 96,9\% puas, dan tempat konseling $100 \%$ puas. Faktor-faktor yang berhubungan dengan kepuasan pasien terhadap konseling gizi adalah materi konseling $(\mathrm{p}=0,031)$ dan lama konseling $(\mathrm{p}=0,031)$. Sikap konselor $(\mathrm{p}=0,062)$, media konseling $(\mathrm{p}=0,469)$, metode konseling $(\mathrm{p}=0,406)$, dan tempat konseling $(\mathrm{p}=1,00)$ tidak berhubungan dengan kepuasan pasien.
\end{abstract}

Kesimpulan: Faktor-faktor yang berhubungan dengan kepuasan pasien terhadap konseling gizi adalah materi konseling dan lama konseling.

Kata Kunci : Konseling Gizi, Kepuasan Pasien

Korespondensi :

Ahmad Yani

Program Studi Ilmu Gizi, STIKes Holistik Purwakarta

Jl. Veteran No. 272 Ciseureuh Purwakarta, Jawa Barat 41118

Email : ahmadyani@holisticindonesia.com

Phone : 0856-5908-7722 


\title{
FACTORS THAT RELATED TO HOSPITALIZATION PATIENTS SATISFICATION TOWARD NUTRIENT COUNSELINGIMPLEMENTATION AT PURWAKARTA HOLISTIC HOSPITAL
}

\begin{abstract}
Background: So far nutrient service in Purwakarta Holistic Hospital never did evaluation about nutrient counseling service seen from medical patient satisfaction aspect. This evaluation process is very important because it is connected with aspects that to be the main priority in nutrient counseling service including counselor attitude, matter, media, method, time, and place of the counseling.

Objective : To find out the factors which connected with hospitalization patients satisfaction toward nutrient counseling implementation in Purwakarta Holistic Purwakarta.

Method : This research used obsevational with approach that used cross sectional. Number of research samples are about 32 people. Data which obtained are about nutrient counseling element, among counselor attitude, matter, media, method, time, and the place of the counseling. Data are obtained by questionnaires. Data analysis is Fisher Exact Test.

Result : This research obtained that respondent assessment toward counselor attitude is $68,8 \%$ satisfied, counseling matter is $87,5 \%$ satisfied, media is $50 \%$ satisfied, counseling method is $46,9 \%$ satisfied, time of counceling is $96,9 \%$ satisfied,and place of counseling is $100 \%$ satisfied. Factors that related patient satisfaction toward nutrient counseling is counselor attitude $(\mathrm{p}=0,062)$, counseling matter $(p=0,031)$, counseling media $(p=0,469)$, counseling method ( $p$ $=0,406)$, time of counseling $(\mathrm{p}=0,031)$, place of counseling $(\mathrm{p}=1,000)$.

Conclusion: Factors that related patient satisfaction toward nutrient counseling are materials of counseling and time of counseling.
\end{abstract}

Keyword : Nutrient Counseling implementation, patient satisfaction 


\section{PENDAHULUAN}

Konseling gizi merupakan pelayanan gizi yang sangat penting, karena setiap orang mempunyai masalah yang berbeda-beda. Peran konselor gizi membantu klien dan pasien dalam mengubah perilaku positif hubungannya dengan makanan dan gizi, mengenali permasalahan kesehatan dan gizi yang dihadapi, mendorong klien untuk mencari cara pemecahan masalah, mengarahkan klien untuk memilih cara pemecahan masalah yang paling sesuai dan membantu proses penyembuhan penyakit melalui perbaikan gizi klien. ${ }^{1}$ Aspekaspek yang diperlukan dalam pelaksanaan konseling gizi meliputi konselor, metode, materi, media, tempat, waktu, dan frekuensi. ${ }^{2}$

Hasil penelitian menunjukkan bahwa ada hubungan antara jenis kelamin, umur, pendidikan, dan pekerjaan pasien dengan kepuasan konseling gizi. ${ }^{3}$ Adapun aspek-aspek dalam pelaksanaan konseling gizi dapat diketahui dari hasil penelitian Deri (2000), bahwa mutu konseling gizi rata - rata 99,7 \% (sangat memuaskan) yang terdiri dari aspek penampilan sebesar $100 \%$, prosedur pelayanan sebesar $99,7 \%$, dan sikap pelayanan petugas sebesar 96,7 \%. Salah satu penelitian menunjukkan bahwa tingkat kepuasan terhadap konselor $100 \%$ puas, metode $89,7 \%$ puas, materi $98,5 \%$ puas, media 91,2 $\%$ puas, tempat $89,7 \%$ puas, lama konseling gizi 80,9 \% puas, dan terhadap frekuensi kunjungan ahli gizi (konselor) 66,2 \% puas. ${ }^{4}$

Rumah Sakit Holistic Purwakarta merupakan Rumah Sakit Kelas D di Provinsi Jawa Barat.Instalasi gizi Rumah Sakit Holistic Purwakarta telah melaksanakan konseling gizi di rawat inap dan rawat jalan.Konselor terdiri dari ahli gizi lulusan S1 Gizi yang menangani pasien.Rumah Sakit Holistic merupakan salah satu rumah sakit yang memiliki konsep bahwa makanan sebagai obat utama, yaitu pemberian diit pada pasien dengan memperbanyak konsumsi sayuran, buah-buahan, umbi-umbian, dengan makanan yang minimal proses pengolahan.

Selama ini pelayanan gizi di Rumah Sakit Holistic Purwakarta belum pernah melakukan evaluasi 
tentang layanan konseling gizi dilihat dari segi kepuasan pasien. Proses evaluasi ini sangat penting dilakukan karena berkaitan dengan aspek-aspek yang menjadi prioritas utama dalam pelayanan konseling gizi yaitu mencakup sikap konselor, materi, media, lama, metode, dan tempat konseling. Dengan dilakukan evaluasi konseling gizi terhadap kepuasan pasien maka akan diketahui aspek-aspek mana saja yang harus diperbaiki dalam pelaksanaan konseling gizi. Pelayanan konseling gizi sebagai salah satu jenis pelayanan yang penting di instalasi gizi berpengaruh terhadap kepercayaan pasien yang mengharapkan pelayanan terbaik, yang pada akhirnya akan berpengaruh pada peningkatan citra rumah sakit, dalam hal ini Rumah Sakit Holistic Purwakarta. Oleh karena itu, penelitian ini penting dilakukan, untuk mengetahui "Faktor-faktor yang Berhubungan dengan Kepuasan Pasien Rawat Inap terhadap Pelaksanaan Konseling Gizi di Rumah Sakit Holistic Purwakarta”.

\section{METODE}

Penelitian ini merupakan jenis penelitian observasional dengan desain cross sectional, Populasi dalam penelitian ini adalah seluruh pasien rawat inap di Rumah Sakit Holistic Purwakarta.Dari hasil perhitungan dengan rumus koefisien korelasi diperoleh jumlah sampel 32 orang. Tehnik Pengambilan sampel dilakukan dengan teknik consecutive sampling.

Instrumenyang digunakan dalam penelitian ini adalah angket yangberisi pertanyaan yang sudah disediakan jawabannya, pertanyaan yang ada dalam angket berupa identitas pasien meliputi nomor urut pengisian angket, jenis kelamin, lama dirawat, umur, dan pekerjaan, konselor, materi, media, metode, lama konseling, dan tempat konseling.Analisis data dilakukan untuk mengetahui faktor apa saja yang berhubungan dengan kepuasan pasien terhadap konseling gizi. Uji yang digunakan adalah UjiFisher Exact Test. 


\section{HASIL PENELITIAN}

Tabel. 1

Distribusi Frekuensi Variabel berdasarkan Karakteristik Responden

\begin{tabular}{|c|c|c|c|}
\hline No. & Variabel & $\mathbf{N}$ & $\begin{array}{c}\text { Persentase } \\
(\%)\end{array}$ \\
\hline \multirow[t]{3}{*}{1} & Jenis Kelamin & & \\
\hline & a. Laki-Laki & 15 & 47 \\
\hline & b. Perempuan & 17 & 53 \\
\hline \multirow[t]{5}{*}{2} & Konselor & & \\
\hline & a. Sangat Puas & 7 & 21,9 \\
\hline & b. Puas & 22 & 68,8 \\
\hline & c. Kurang Puas & 3 & 9,4 \\
\hline & d. Tidak Puas & 0 & 0,0 \\
\hline \multirow[t]{5}{*}{3} & Materi & & \\
\hline & a. Sangat Puas & 3 & 9,4 \\
\hline & b. Puas & 28 & 87,5 \\
\hline & c. Kurang Puas & 1 & 3,1 \\
\hline & d. Tidak Puas & 0 & 0,0 \\
\hline \multirow[t]{5}{*}{4} & Media & & \\
\hline & a. Sangat Puas & 1 & 3,1 \\
\hline & b. Puas & 16 & 50,0 \\
\hline & c. Kurang Puas & 0 & 0,0 \\
\hline & d. Tidak Puas & 15 & 46,9 \\
\hline \multirow[t]{5}{*}{5} & Metode & & \\
\hline & a. Sangat Puas & 2 & 6,3 \\
\hline & b. Puas & 15 & 46,9 \\
\hline & c. Kurang Puas & 14 & 43,8 \\
\hline & d. Tidak Puas & 1 & 3,1 \\
\hline \multirow[t]{5}{*}{6} & Lama Konseling & & \\
\hline & a. Sangat Puas & 0 & 0,0 \\
\hline & b. Puas & 31 & 96,9 \\
\hline & c. Kurang Puas & 1 & 3,1 \\
\hline & d. Tidak Puas & 0 & 0,0 \\
\hline \multirow[t]{5}{*}{7} & Tempat Konseling & & \\
\hline & a. Sangat Puas & 0 & 0,0 \\
\hline & b. Puas & 32 & 100,0 \\
\hline & c. Kurang Puas & 0 & 0,0 \\
\hline & d. Tidak Puas & 0 & 0,0 \\
\hline
\end{tabular}


Tabel.2

Faktor-faktor yang berhubungan dengan kepuasan pasien terhadap pelaksanaan konseling gizi Di Rumah Sakit Holistic Puwakarta 2016

\begin{tabular}{|c|c|c|c|c|c|c|}
\hline \multirow{3}{*}{ No } & \multirow{3}{*}{ Variabel } & \multicolumn{4}{|c|}{ Kepuasan Pasien } & \multirow{3}{*}{$\mathbf{p}^{\mathbf{a}}$} \\
\hline & & \multicolumn{2}{|c|}{ Tidak Puas } & \multicolumn{2}{|c|}{ Puas } & \\
\hline & & $\mathbf{N}$ & $\%$ & $\mathbf{N}$ & $\%$ & \\
\hline \multirow[t]{3}{*}{1.} & Konselor & & & & & \\
\hline & a. $<$ median & 1 & 3,1 & 1 & 3,1 & 0,062 \\
\hline & b. $\geq$ median & 0 & 0,0 & 30 & 93,8 & \\
\hline
\end{tabular}

2. Materi

$\begin{array}{lllccc}\text { a. < median } & 1 & 3,1 & 0 & 0,0 & 0,031^{*} \\ \text { b. } \geq \text { median } & 0 & 0,0 & 31 & 96,9 & \end{array}$

3. Media

$\begin{array}{llllll}\text { a. < median } & 1 & 3,1 & 14 & 43,8 & 0,469 \\ \text { b. } \geq \text { median } & 0 & 0,0 & 17 & 53,1 & \end{array}$

4. Metode
a. < median
3,1
12
$37,5 \quad 0,406$
b. $\geq$ median
0,0
$19 \quad 59,4$

5. Lama

$\begin{array}{lllccc}\text { konseling } & 1 & 3,1 & 0 & 0,0 & 0,031^{*} \\ \text { a. < median } & 0 & 0,0 & 31 & 96,9 & \\ \text { b. } \geq \text { median } & & & & & \end{array}$

6. Tempat

$\begin{array}{lllccc}\text { Konseling } & 0 & 0,0 & 9 & 28,1 & 1,000 \\ \text { a. < median } & 1 & 3,1 & 22 & 68,8 & \\ \text { b. } \geq \text { median } & & & & & \end{array}$

${ }^{\mathrm{a}}$ Fisher Exact Test

*nilai ( $p$ value $:<0,05)$

Berdasarkan uji Fisher Exactvariabel yang berhubungan dengan kepuasan pasien terhadap pelaksanaan konseling gizi adalah materi konseling $(\mathrm{p}=0,031)$ dan tempat konseling $(\mathrm{p}=0,031)$.

\section{PEMBAHASAN}

\section{Karakteristik Responden}

Distribusi

responden

berdasarkan jenis kelamin menunjukkan bahwa responden perempuan sebesar $53 \%$ lebih banyak dibandingkankan responden laki-laki sebesar 47\%. Responden perempuan lebih dominan dibandingkan responden laki-laki dikarenakan pada saat pengambilan data jumlah populasi pasien perempuan lebih banyak dibandingkan laki-laki. 


\section{Sikap Konselor}

Dari hasil penelitian diketahui bahwa sebagian besar responden merasa puas terhadap sikap konselor didapatkan 68,8\%, kemudian $21,9 \%$ pasien merasa sangat puas, 9,4\% merasa kurang puas dan tidak ada yg merasa tidak puas. Hasil penelitian ini serupa dengan penelitian yang dilakukan oleh Martiana (2006) menunjukkan bahwa tingkat kepuasan terhadap konselor $100 \%$ puas. ${ }^{4}$ Dasar dari keterampilan konselor adalah keterampilan komunikasi yang baik dengan menggunakan berbagai cara berkomunikasi, respon mendengar, melakukan, dan saling berbagi. ${ }^{1}$ Dari hasil observasi responden merasakan keramahan konselor, penampilan konselor yang rapih dan bersih serta konselor mendengarkan dengan baik ketika responden berbicara.

\section{Materi konseling}

Menunjukkan bahwa sebagian besar responden merasa puas terhadap materi konseling yaitu sebesar 87,5\%, responden yang merasa sangat puas sebesar 9,4\%, responden yang merasa kurang puas sebesar 3,1\% dan yang merasa tidak puas $0,0 \%$. Materi konseling disesuaikan dengan permasalahan pasien.

Pemberian materi dilakukan secara bertahap mengingat manusia mempunyai keterbatasan. Penjelasan diawali tentang hal-hal yang mudah sampai hal yang rumit, dari yang bersifat umum kepada hal-hal yang lebih bersifat khusus. ${ }^{5}$ Dari hasil observasi responden sebagian besar merasa puas karena materi yang disampaikan sudah sesuai dengan penyakit yang diderita responden serta materi yang disampaikan dapat mudah dipahami oleh responden.

\section{Media Konseling}

Menunjukan bahwa responden yang merasa puas terhadap media konseling yaitu sebesar 50,0\%, responden yang merasa sangat puas sebesar 3,1\%, responden yang merasa kurang puas sebesar $0,0 \%$ dan yang tidak puas sebesar 46,9\%. Manfaat alat peraga yang paling utama adalah memperjelas pesan-pesan yang akan disampaikan, juga dapat menambah 
efektivitas proses pendidikan dan konseling gizi. ${ }^{6}$

Hasil penelitian di Rumah Sakit Umum Mataram menyatakan penilaian responden terhadap media dengan menggunakan leaflet dan bahan penukar makanan penukar sebesar $\quad 91,2 \% \quad$ sangat puas. ${ }^{7}$ Kepuasan pasien yang dihasilkan pada faktor media konseling terdapat kelemahan sehingga hasil penelitian sebesar $46,9 \%$ responden merasa tidak puas, data pada angket lebih merujuk kepada konseling pulang. Pemberian media seperti leaflet diberikan pada saat konseling pulang, sedangkan data responden yang diambil lengkap yaitu konseling yang dilakukan pada saat konseling datang dan konseling pulang sebanyak 17 responden dan 15 responden hanya dapat diambil data konseling awal saja karena lamanya rawat inap Di Rumah Sakit Holistic Purwakarta, sehingga peneliti mengalami keterbatasan waktu penelitian.

\section{Metode Konseling}

Menunjukan

bahwa

responden merasa puas terhadap metode konseling yaitu sebesar $46,9 \%$, responden yang merasa sangat puas sebesar $6,3 \%$, responden yang merasa kurang puas sebesar 43,8\% dan yang tidak puas sebesar $3,1 \%$, ini bisa disebabkan oleh kelemahan penelitian yaitu tidak lengkapnya data yang didapatkan karena keterbatasan waktu penelitian.

\section{Lama Konseling}

Menunjukkan bahwa sebagian besar responden merasa puas terhadap lama konseling yaitu sebesar 96,9\%, responden yang merasa kurang puas sebesar $3,1 \%$ dan responden yang merasa tidak puas $0,0 \%$.

Penelitian yang dilakukan Martiana (2006) menunjukkan bahwa tingkat kepuasan terhadap lama konseling gizi $80,9 \quad \%$ puas. ${ }^{4}$ Lama yang dilakukan untuk konseling tergantung dari kasus yang ditangani dan tidak dapat ditentukan secara pasti. Lama atau waktu yang baik untuk konseling adalah selama 30 sampai 60 menit, dengan pembagian waktu kira-kira 30 menit untuk menggali data dan selebihnya untuk diskusi dan pemecahan 
masalah. ${ }^{5}$ Dari hasil observasi yang dilakukan sebagian besar responden merasa puas terhadap lama konseling karena lama konseling \pm 30 menit sehingga responden dapat berdiskusi dengan konselor lebih leluasa.

\section{Tempat Konseling}

Menunjukkan bahwa semua responden merasa puas terhadap tempat konseling yaitu sebesar 100\%. Dari hasil observasi responden merasa nyaman dengan kamar yang dipakai konseling baik dari segi penerangan, kebersihan sampai sirkulasi udara yang masuk ke dalam ruangan.

Hasil Penelitian ini serupa dengan penelitian Martiana (2006) menyatakan sebagian besar responden merasa nyaman dengan tempat konseling gizi sebesar $89,7 \%{ }^{4}$ Pada prinsipnya konseling bisa dilaksanakan dimana saja asal memenuhi konsep kenyamanan dan informasi yang disampaikan klien tidak didengar orang yang tidak berkepentingan serta dijamin kerahasiaannya. ${ }^{6}$

\section{Hubungan Konselor terhadap Kepuasan Pasien}

Konselor adalah seseorang yang memiliki keahlian dalam bidang pelayanan konseling dan tenaga professional. Berdasarkan penelitian hubungan konselor terhadap kepuasan pasien didapat $\mathrm{p}=0,062$ yang menunjukan tidak adanya hubungan yang signifikan antara konselor dan kepuasan pasien. Hasil penelitian ini bertentangan dengan penelitian Sulasty (2008) Untuk waktu, tempat dan konselor berhubungan dengan tingkat kepuasan pasien dalam pelaksanaan konseling gizi. ${ }^{7}$

Dari hasil observasi didapatkan bahwa penilaian responden sudah puas dengan sikap konselor namun kepuasan pasien bersifat obyektif seperti teori. Kepuasan pasien merupakan nilai subyektif terhadap kualitas pelayanan yang diberikan. Subyektifitas pasien dipengaruhi oleh pengalaman pasien dimasa lalu, pendidikan, situasi psikis saat itu, dan pengaruh lingkungan. 
Hubungan Materi Konseling terhadap Kepuasan Pasien

Materi adalah sesuatu yg menjadi bahan untuk diujikan, dipikirkan, dibicarakan, dikarangkan. Berdasarkan hasil penelitian didapatkan $(\mathrm{p}$ value $=0,031)$, ini menunjukan bahwa ada hubungan yang signifikan antara materi konseling terhadap kepuasan pasien. Penelitian ini serupa dengan penelitian Martiana menunjukkan bahwa ada hubungan tingkat kepuasan pasien dengan pelaksanaan konseling gizi dari segi materi konseling 98,5\%. ${ }^{4}$ Dari hasil observasi responden merasa puas terhadap materi konseling karena materi yang diberikan dapat dipahami responden serta materi yang disampaikan sesuai dengan kondisi penyakit pasien.

\section{Hubungan Madia Konseling} terhadap Kepuasan Pasien

Media (bentuk jamak dari kata medium), merupakan kata yang berasal dari bahasa latin medius, yang secara harfiah berarti 'tengah', 'perantara' atau 'pengantar'. Oleh karena itu, media dapat diartikan sebagai perantara atau pengantar pesan dari pengirim ke penerima pesan. Media dapat berupa seusatu bahan (software) dan alat (hardware).

Berdasarkan hasil penelitian diketahui $(\mathrm{p}$ value $=0,469)$, menunjukan bahwa tidak ada hubungan yang signifikan antara media konseling terhadap kepuasan pasien. Hasil penelitian ini serupa dengan penelitian yang dilakukan Sulasty (2008) menunjukkan bahwa tingkat kepuasan pasien tidak ada hubungannya dengan sikap, materi, metode, dan media terhadap pelaksanaan konseling gizi. Hal ini dapat disebabkan oleh faktor-faktor lain yang mempengaruhi kepuasan pasien. $^{7}$

\section{Hubungan Metode Konseling terhadap Kepuasan Pasien}

Metode adalah teknik-teknik yang digeneralisasikan dengan baik agar dapat diterima atau digunakan secara sama dalam satu disiplin, praktek, atau bidang disiplin dan praktik. Hasil penelitian ini didapatkan $(\mathrm{p}$ value $=0,406)$, menunjukan bahwa tidak ada 
hubungan yang signifikan antara metode konseling terhadap kepuasan pasien. Hal ini disebabkan kepuasan pasien didapat dari faktor lain, seperti pada isi materi konseling yang disampaikan. Hasil penelitian ini serupa dengan penelitian Sulasty (2008) menunjukkan bahwa tingkat kepuasan pasien tidak ada hubungannya dengan sikap, metode, dan media terhadap pelaksanaan konseling gizi.

Hubungan Lama Konseling terhadap Kepuasan Pasien

Hasil dari uji Fisher Exactterdapat hubungan yang signifikan antara lama konseling terhadap kepuasan pasien didapatkan $(\mathrm{p}$ value $=0,031)$. Hasil observasi lama konseling rata-rata dilakukan \pm 30 menit setiap pasien, dalam waktu sebanyak itu pasien dapat bertanya ataupun melakukan diskusi dengan konselor lebih leluasa sehingga pasien merasa puasa terhadap lamanya konseling yang diberikan.

\section{Hubungan Tempat Konseling} terhadap Kepuasan Pasien
Hasil penelitian uji Fisher Exact menunjukan bahwa tidak ada hubungan yang signifikan antara tempat konseling terhadap kepuasan pasien ( $\mathrm{p}$ value $=1,000$ ). Penelitian ini bertentangan dengan penelitian yang dilakukan oleh Sulasty (2008) menunjukkan bahwa tingkat kepuasan pasien ada hubungan dengan waktu, tempat dan frekuensi kunjungan konselor berhubungan dengan tingkat kepuasan pasien dalam pelaksanaan konseling gizi. ${ }^{7}$

Dari hasil observasi masih ada beberapa responden kehabisan kamar yang sesuai dengan keinginan, air keruh dan air kurang lancar mengalir juga menjadi faktor yang mengganggu kenyamanan responden. Konseling gizi dilakukan diruang rawat inap sehingga informasi yang disampaikan responden kurang terjamin kerahasiaannya karena ruangan tidak kedap suara.

Faktor-faktor yang Berhubungan dengan Pelaksanaan Konseling Gizi terhadap Kepuasan Pasien

Adanya konseling gizi, responden merasa dibantu untuk 
mempercepat kesembuhan penyakitnya dan lebih percaya diri. Kepuasan adalah harapan pelanggan akan hasil kinerja yang diberikan, pelayanan yang diberikan dan harga yang sudah ditentukan sehingga tercipta keputusan yang dapat mempengaruhi kepuasan pelanggan dan dapat memberikan kepercayaan. ${ }^{8}$

Berdasarkan uji Fisher Exact didapatkan faktor materi konseling ( $p$ value $=0,031)$ yang menunjukan ada hubungan yang signifikan terhadap kepuasan pasien Di Rumah Sakit Holistic Purwakarta. Faktor yang berhubungan terhadap kepuasan pasien juga didapatkan pada faktor lama konseling ( $\mathrm{p}$ value $=0,031$ ) yang menunjukan ada hubungan yang signifikan terhadap kepuasan pasien Di Rumah Sakit Holistic Purwakarta. Nilai $\mathrm{p}=0.031(\mathrm{p}<0,05)$ sehingga faktor-faktor yang berhubungan terhadap kepuasan pasien rawat inap terhadap pelaksaan konseling gizi Di Rumah Sakit Holistic Purwakarta dari faktor materi konseling dan lama konseling adalahsignifikan (bermakna). Sehingga dapat dikatakan bahwa apabila materi konseling yang diberikan kepada pasien dapat dipahami dan materi sesuai dengan kondisi penyakit pasien serta lama konseling yang diberikan berkualitas maka akan berbanding lurus terhadap peningkatan kepuasan pasien Di Rumah Sakit Holistic Purwakarta.

Penelitian ini serupa dengan penelitian Anik Suparni (2014) Ada hubungan yang signifikan antara pelaksanaan konseling gizi dengan kepuasan pasien (nilai $\mathrm{p}=0,000$ ) di RSUD dr. Soehadi Prijonegoro Sragen. Depkes RI (1991) menyatakan aspek-aspek yang diperlukan dalam pelaksanaan konseling gizi yaitu pola pelaksanaan kegiatan konseling gizi yang terdiri dari cara pendekatan yang dilakukan, materi, waktu dan frekuensi. ${ }^{2}$ Depkes dan Kessos (2000) menyebutkan persyaratan penyelenggaraan konseling gizi meliputi persyaratan konselor, kondisi klien, tempat dan lama, makanan yang dianjurkan. ${ }^{5}$

\section{SIMPULAN}

Tidak ada hubungan pengetahuan konselor terhadap kepuasan pasien $(\mathrm{p}=0,062)$, ada hubungan materi terhadap kepuasan pasien $(\mathrm{p}=0,031)$, 
tidak ada hubungan media konseling terhadap kepuasan pasien $(\mathrm{p}=0,469)$, tidak ada hubungan metode konseling terhadap kepuasan pasien $(\mathrm{p}=0,406)$, ada hubungan lama konseling terhadap kepuasan pasien $(\mathrm{p}=0,031)$, tidak ada hubungan tempat konseling terhadap kepuasan pasien $(\mathrm{p}=1,000)$.

\section{DAFTAR PUSTAKA}

1. Persatuan Ahli Gizi Indonesia.Konseling Gizi. Jakarta: Penebar Swadaya Grup; 2013.

2. Departemen Kesehatan RI. Buku Pedoman Pengelolaan Pelayanan Gizi Rumah Sakit. Jakarta: Dirjen Pelayanan Medik Direktorat Rumah Sakit Khusus dan Swasta; 1991.

3. Umarella, M. Kepuasan Pasien Rawat Inap terhadap Pelayanan Gizi Puskesmas Perawatan Pusat Gugus Kairatu Kabupaten Maluku Tengah (Thesis).Yogyakarta: Universitas Gajah Mada; 1998.

4. Martiana.Tingkat Kepuasan Pasien Rawat Inap terhadap
Pelaksanaan Konsultasi Gizi Ruangan di RSUD Banyumas (Undergraduate Thesis). Yogyakarta: Universitas Gadjah Mada; 2006.

5. Depkes dan Kessos RI. Pedoman Konseling Gizi (Buku Modul Akademi Gizi). Jakarta: Dirjen Kesehatan Masyarakat Direktorat Gizi Masyarakat; 2000.

6. Supariasa. Pendidikan Dan Konsultasi Gizi. Jakarta : EGC; 2012.

7. Sulasty, SU. Faktor-Faktor yang Berhubungan dengan Tingkat Kepuasan Pasien Rawat Inap terhadap Pelaksanaan Konsultasi Gizi Ruangan di Rumah Sakit Umum Mataram. Yogyakarta: Skripsi Program Studi S-1 Gizi Kesehatan Fakultas Kedokteran Universitas gadjah Mada; 2008.

8. Santoso. Analisis Pengaruh Pelayanan terhadap Kepuasan Pasien Rawat Inap Kelas III pada Rumah Sakit Roemani Muhammadiyah Semarang.Semarang: Universitas Diponegoro; 2012. 